\title{
Buxus sirindhorniana sp. nov. (Buxaceae), a bicarpellate species from Thailand
}

\author{
Wuu Kuang Soh, Maximilian von Sternburg ${ }^{\dagger}$, Trevor R. Hodkinson and John A. N. Parnell \\ W. K. Soh (sohw@tcd.ie), M. von Sternburg, T. R. Hodkinson and J. A. N. Parnell, Botany Dept, School of Natural Sciences, Trinity College \\ Dublin, Ireland; and Trinity Centre for Biodiversity Research, Trinity College Dublin 3, Ireland.
}

\begin{abstract}
A new bicarpellate Buxus species, Buxus sirindhorniana W. K. Soh, M. von Sternburg, Hodk. \& J. Parn., is described from northern Thailand. This is the first reported bicarpellate species of Buxus. The pollen morphology and the degree of pollen viability of the species are reported. DNA was extracted from herbarium samples and the internal transcribed spacer (ITS) region of nuclear ribosomal DNA sequenced. The palynological evidence and the phylogenetic reconstruction support the contention that this new species belongs to the genus Buxus. The morphological diversity of reproductive organs in the Buxaceae, in relation to this new species, is briefly discussed.
\end{abstract}

Buxaceae includes the genera Buxus, Haptanthus, Notobuxus, Pachysandra, Sarcococca and Styloceras (Köhler 2006, Shipunov and Shipunova 2011). Based on the study of nuclear and plastid (chloroplast) DNA (von Balthazar et al. 2000), two strongly supported major monophyletic groups are recognised, the first group is Buxus with Notobuxus and the second group consists of Pachysandra, Sarcococca and Styloceras. Notobuxus is now widely recognised as a section under Buxus (Tropicos 2013). African Buxus, American Buxus, Eurasian Buxus and Sarcococca each form strongly supported clades (von Balthazar et al. 2000) but the relationship within the Buxus and Sarcococca clades was not, however, fully resolved. Haptanthus, a monotypic taxon which was prviously placed in its own family Haptanthaceae, is now grouped in Buxaceae based on DNA evidence (Shipunov and Shipunova 2011).

The only genera of Buxaceae that occur in Thailand are Buxus and Sarcococca. In the course of a taxonomic revision of Buxaceae for the 'Flora of Thailand Project' (Parnell 2003), we discovered a new species which possessed characters of both genera. This is the second Buxus species for Thailand after $B$. cochinchinensis Pierre ex. Gagnep. This new species is similar to Sarcococca in having a bicarpellate ovary but it is also similar to Buxus in having a single terminal female flower, laterally inserted male flowers and decussate leaves. Herbarium specimens belonging to this new species have previously been identified either as Sarcococca or Buxus. Sealy (1986), who had revised Sarcococca, annotated the specimen Kerr 6131 as S. coriacea (Hook.) Sweet. The pollen of this new species, was studied by Brückner (1993) as an unidentified

${ }_{\dagger}$ Maximilian von Sternburg deceased in February 2013.
Buxus species (Smitinand 4702, Hennipman 3194), and found to resemble the pollen type of the genus Buxus.

This paper determines the generic status of this new Buxaceae taxon and describes it as a new species.

\section{Material and methods}

\section{Macro-morphology and taxonomy}

Herbarium specimens of the new taxon were acquired from BKF, $\mathrm{K}$ and P. Vegetative and reproductive structures were measured and described following traditional herbarium taxonomy methods (Vogel 1987). Flowers and fruits were boiled and dissected under a Leica M50 stereo microscope. Specimens of Buxus and Sarcococca including types from BKF, K, KEP, P, TCD and US were compared to the new taxon. In addition to this, online type images were downloaded from A, GH, L and NY.

\section{Pollen type and viability}

We used a Tescan Mira XMU scanning electron microscopy (SEM) to determine pollen morphology. Unacetolyzed pollen (Maxwell 96-1672, BKF) was fixed on adhesive tape and coated with gold palladium. The descriptive terminology followed mainly Erdtman (1952).

The detection of decreased pollen viability in plants is commonly used along with other evidence, for the identification of hybrids. We assessed the pollen viability of three flowering herbarium specimens (Hennipman 3194, Maxwell 96-1672, Smitinand 4702) from BKF by staining 
with aniline blue in lactophenol (Dafni 1992). Inviable pollen was counted as that which remained unstained or was distorted. Therefore, pollen that stained blue and was not deformed was considered viable. The anthers were removed from a closed or newly opened young flower and dissected on a microscope slide in a drop of aniline bluelactophenol solution. The anthers were macerated, the sacs removed and the preparation left for $30 \mathrm{~min}$ for the pollen to pick up the stain. The pollen was then observed at $200 \times$ using an Olympus BX60 light microscope. Three to five samples were prepared from each herbarium specimen. The number of unstained and/or distorted grains in a sample of $80-100$ pollen grains per preparation was counted to assess pollen inviability.

\section{Molecular studies}

Herbarium specimens from BKF (Hennipman 3194, Maxwell 96-113, Maxwell 96-1487, Maxwell 96-1672, Smitinand and Anderson 7228, Smitinand 4210, Smitinand 4702) were used for the DNA extraction. Total cellular DNA was extracted using the DNeasy Plant Mini Kit according to the manufacturer's protocol. The internal transcribed spacers (ITS) of nuclear ribosomal DNA (nrDNA) were used in this study. Three sets of primers were used to amplify the entire ITS region of nrDNA: ITS5M (Liston et al. 1996) and ITS25R (Nickrent et al. 1994), ITS5/ITS2 (White et al. 1990) and ITS3/ITS4 (White et al. 1990). For the PCR amplification, each reaction mixture $(25 \mu \mathrm{l})$ contained $14.38 \mu \mathrm{l}$ of sterile water, $5 \mu \mathrm{l}$ of $5 \times$ Taq polymerase reaction buffer, $2.5 \mu \mathrm{l}$ of $25 \mathrm{mmol} \mathrm{l}^{-1} \mathrm{MgCl}_{2}, 0.5 \mu \mathrm{l}$ of $10 \mathrm{mmol} \mathrm{l}^{-1}$ dNTPs, $0.25 \mu \mathrm{l}$ of each of the two primers (100 ng $\mu \mathrm{l}^{-1}$ ), $0.13 \mu \mathrm{l}$ (5 units $\mu \mathrm{l}^{-1}$ ) of Taq polymerase and $2 \mu \mathrm{l}$ of genomic DNA template (20-50 ng). PCRs were performed using a Biometra T Professional Gradient thermal cycler under the conditions of $95^{\circ} \mathrm{C}$ for $90 \mathrm{~s}$ (premelting), 32 cycles of $95^{\circ} \mathrm{C}$ for $30 \mathrm{~s}$ (denaturation), $55^{\circ} \mathrm{C}$ for $1 \mathrm{~min}$ (annealing) and $72^{\circ} \mathrm{C}$ for $90 \mathrm{~s}$ (extension), and finally $72^{\circ} \mathrm{C}$ for $7 \mathrm{~min}$ (final extension). The PCR product was purified with the ExoSap Purification Kit. Cycle sequencing reactions were carried out using the BigDye Terminator Mix and the same primers as above. The sequencing protocol consisted of 28 cycles of $96^{\circ} \mathrm{C}$ for $1 \mathrm{~min}$ (premelting), $96^{\circ} \mathrm{C}$ for $10 \mathrm{~s}$ (denaturation), $50^{\circ} \mathrm{C}$ for $5 \mathrm{~s}$ (annealing) and $60^{\circ} \mathrm{C}$ for $4 \mathrm{~min}$ elongation. Products were run on ABI Prism 3130xl Genetic Analyser according to the manufacturer's protocol.

We were only able to amplify the ITS region from a single sample of the new taxon, Maxwell 96-1672. We obtained a $776 \mathrm{bp}$ fragment, from which we constructed a phylogenetic tree using 25 other taxa from von Balthazar et al. (2000) (Table 1). We did not detect any polymorphic sites (multiple trace peaks) in the nucleotide sequence of the new taxon sequence. The sequences were analysed and assembled using Geneious ver. 6. The coding of hypothesised insertion and deletion events was not attempted. Parsimony analyses were performed using PAUP ver. $4.0 \mathrm{~b}$ 10 (Swofford 2002). General heuristic search strategies were performed using 1000 replicates of random stepwise
Table 1. GenBank accession numbers for sequences used in the phylogenetic reconstruction.

\begin{tabular}{ll}
\hline Taxon & Accession no. \\
\hline Buxus balearica Wild. & AF245423 \\
Buxus citrifolia (Wild.) Spreng. & AF245433 \\
Buxus glomerata (Griseb.) Müll. Arg. & AF245426 \\
Buxus gonoclada (Wright ex Griseb.) Müll. Arg. & AF245427 \\
Buxus harlandii Hance & AF245410 \\
Buxus henryi Mayr & AF245409 \\
Buxus hildebrandtii Baill. & AF245415 \\
Buxus liukiuensis Makino & AF245428 \\
Buxus macowanii Oliv. & AF245411 \\
Buxus microphylla Siebold \& Zucc. subsp. & AF245414 \\
sinica Hatusima & \\
Buxus microphylla Siebold \& Zucc. var. & AF245412 \\
japonica & \\
Buxus riparia Makino & AF245413 \\
Buxus sempervirens L. & AF245429 \\
Buxus sirindhorniana W. K. Soh, M. von & KF447777 \\
Sternburg, T. Hodkinson \& J. Parn. & \\
Notobuxus acuminata (Gilg) Hutch. & AF245434 \\
Notobuxus natalensis (Oliv.) Hutch. & AF245425 \\
Pachysandra axillaris Franch. subsp. axillaris & AF245420 \\
Pachysandra axillaris subsp. stylosa Dunn & AF245424 \\
Pachysandra procumbens Michx. & AF245421 \\
Pachysandra terminalis Siebold \& Zucc. & AF245430 \\
Sarcococca confertiflora Sealy & AF245416 \\
Sarcococca hookeriana var. humilis Baill. & AF245419 \\
Sarcococca ruscifolia var. ruscifolia Stapf & AF245417 \\
Sarcococca saligna (D. Don) Müll. Arg. & AF245418 \\
Sarcococca wallichii Stapf & AF245422 \\
Styloceras brokawii A. Gentry \& R. Foster & AF245431 \\
Didymeles perrieri Olivier Leandri & AF245432 \\
\hline & \\
&
\end{tabular}

addition, saving no more than 100 trees per replicate (to avoid time swapping on large islands of trees), and tree-bisection-reconnection (TBR) branch-swapping with MULPARS on (keeping multiple equally most parsimonious trees). Gaps were treated as missing, multi-state characters were interpreted as uncertainty, all characters were unordered and had equal weight. Strict consensus trees were obtained. For clade support, bootstrap support (Felsenstein 1985) was estimated based on 1000 replicates with the same settings as in the heuristic search, but with only 10 replicates of random stepwise additions per bootstrap replicate.

Bayesian analyses were performed using MrBayes ver. 3.2.1 (Ronquist and Huelsenbeck 2003). The best-fit evolutionary model was estimated using Akaike information criterion test (AIC) and Bayesian information criterion test (BIC) implemented in jModelTest ver. 2. (Darriba et al. 2012). The transition model of substitution with invariable sites and gamma distribution $(\mathrm{TIM}+\mathrm{I}+\mathrm{G})$ was selected. However, we used a general time reversible model of substitution with gamma distribution and invariable sites $(\mathrm{GTR}+\mathrm{I}+\mathrm{G})$ because this is the best matching model available in MrBayes. The Monte Carlo Markov chain was run for 500000 generations with four chains, at the temperature of 0.2 and sampling at every 100 th cycle. Convergence was achieved when the standard deviation of split frequencies was less than 0.01 . The stationary phase was also confirmed by plotting generations vs $\log$ likelihoods using Tracer ver. 1.4.1 (Rambaut and Drummond 2007). The first $25 \%$ of the 5000 trees 

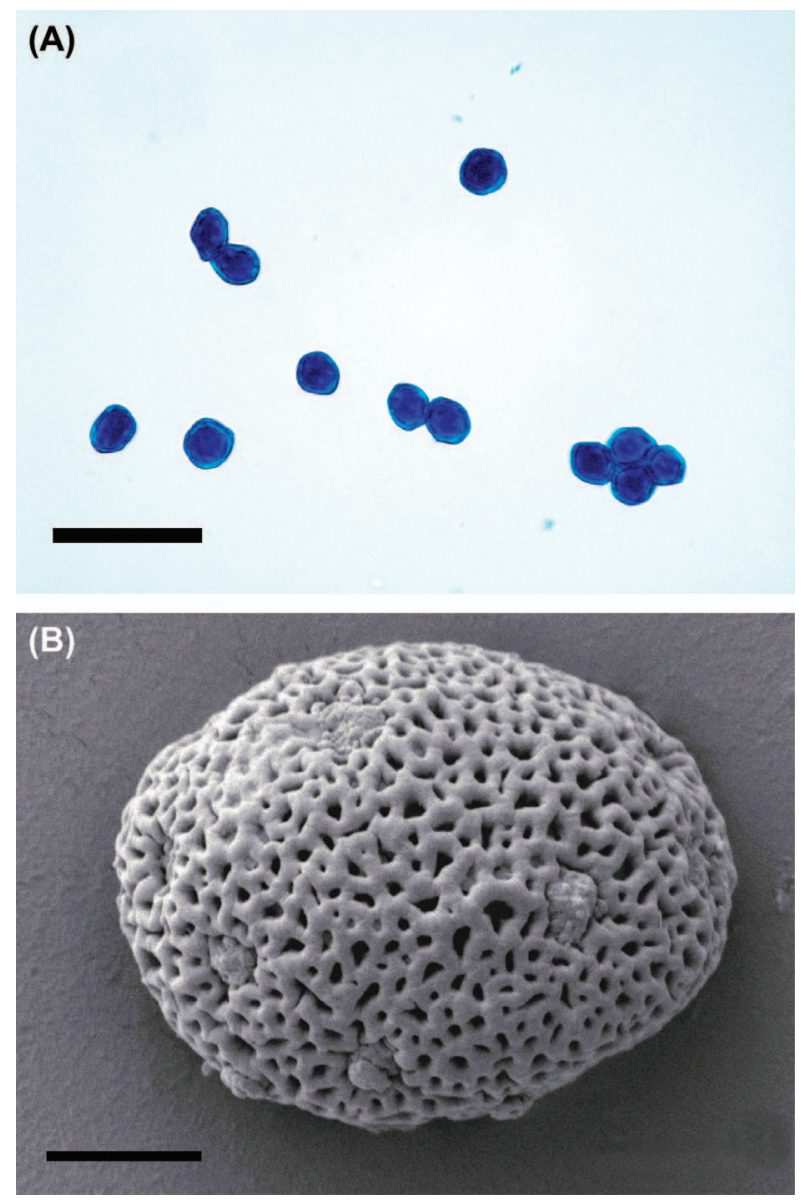

Figure 1. Buxus sirindhorniana sp. nov. (Maxwell 96-1672). (A) pollen grains stained with aniline blue-lactophenol, scale bar $=50 \mu \mathrm{m}$, (B) a whole pollen grain, SEM $\times 8800$, scale bar $=$ $5 \mu \mathrm{m}$.

was discarded as burn-in, and the posterior distribution of trees was summarised using the 'allcompat' consensus.

\section{Results}

The pollen type of Maxwell 96-1672 is similar to Hennipman 3194 and Smitinand 4702 as shown in Brückner (1993) (Fig. 1B). The pollen type of our unknown species clearly places it in the genus Buxus as it has a reticulate sexine rather than the crotonoid sexine of Sarcococca (Erdtman 1952). The following pollen description of our new species is based on this study and Brückner (1993)

Table 2. Pollen size of Buxus sirindhorniana sp. nov.

\begin{tabular}{|c|c|c|c|c|c|}
\hline \multirow[b]{2}{*}{ Voucher } & \multirow{2}{*}{$\begin{array}{l}\text { Pollen } \\
\text { diameter } \\
(\mu \mathrm{m})\end{array}$} & \multicolumn{2}{|r|}{ Aperture } & \multicolumn{2}{|c|}{$\begin{array}{c}\text { Sculpture } \\
\text { diameter }(\mu \mathrm{m})\end{array}$} \\
\hline & & Number & Diameter $(\mu \mathrm{m})$ & Lumina & Muri \\
\hline $\begin{array}{c}\text { Smitinand } \\
4702\end{array}$ & $22(19-25)$ & $12-14$ & $1.5-2.5$ & $0.5-1.5$ & $0.5-1.0$ \\
\hline $\begin{array}{l}\text { Hennipman } \\
3194\end{array}$ & $24.8(21-28)$ & $12-16$ & $1.5-2.0$ & $0.3-1.0$ & $0.5-1.5$ \\
\hline $\begin{array}{l}\text { Maxwell } \\
\text { 96-1672 }\end{array}$ & $18.4(17-20)$ & $10-15$ & $1.4-2.3$ & $0.3-0.9$ & $0.4-0.8$ \\
\hline
\end{tabular}

(Table 2): Pollen pantoporate, $17-28 \mu \mathrm{m}$ diameter. Pori 10-16, 1.4-2.5 diameter, more or less rounded, and partly covered with reticulum. Exine coarsely reticulate. Muri $0.4-1.5 \mu \mathrm{m}$, more or less equal in width, thick, rounded, smooth, with thick or sunken murus at places. Lumina variable $1.4-2.5 \mu \mathrm{m}$ diameter, irregularly shaped, usually angular. The pollen viability of all three herbarium specimens was between $90-95 \%$. This suggests that the new species has high pollen viability (Fig. 1A).

A single most parsimonious tree was generated from the parsimony analysis of the ITS data set (Fig. 2). The tree length was 1636 with consistency index (CI) of 0.652 and retention index (RI) of 0.748 . The tree topology was congruent with that of von Balthazar et al. (2000). The new taxon belongs to the Eurasian Buxus clade with strong support (bootstrap and posterior probability value of $100 \%)$.

\section{Buxus sirindhorniana W. K. Soh, M. von Sternburg, Hodk. \& J. Parn. sp. nov. (Fig. 3, Supplementary material Appendix A1)}

Buxo rupicola Ridl. foliis sine venis intramarginalibus et inflorescentia pubescente similis, sed ab ea foliis lanceolatis apice acuto, floribus bicarpellatis differt.

Type: Thailand, Chiang Mai, Doi Chieng Dao, Hennipman 3194 (holotype: BKF!, isotypes: K!, C).

\section{Etymology}

The specific epithet is chosen to honour Her Royal Highness Princess Maha Chakri Sirindhorn of Thailand, who is a strong advocate for the preservation of biodiversity in the country.

\section{Description}

Shrub or small tree, to $8 \mathrm{~m}$ tall, to $26 \mathrm{~cm} \mathrm{dbh}$, bark whitish, cracked and corky; twigs terete or subangular, striate and lenticellate, $2-3 \mathrm{~mm}$ diameter. Leaves decussate; petiole $0.5-1.0 \mathrm{~cm}$ long; blade coriaceous, lanceolate, $7.5-13 \times 1.5-2.8 \mathrm{~cm}$, attenuate at base, acute at apex; margin slightly revolute; midrib prominent, raised above, sunken below; intramarginal veins absent; secondary veins faint, 25-30 pairs, $0.5-3.0 \mathrm{~mm}$ apart, ca 45 degrees from midrib, arcuate (eucamptodromous), sometimes branched; tertiary veins obscure, reticulate. Inflorescence axillary, hairy, botryoid, to $1.3 \mathrm{~cm}$ long, flowers greenish, male flowers 8-12, inserted laterally, female flowers solitary, terminal; bract ovate, acuminate, $2.0-2.5 \mathrm{~mm}$ long, fimbriate. Male flowers pedicellate, ca $4 \mathrm{~mm}$ long (excluding stamen); pedicel 1.5-2.0 mm long; bract ovate, acuminate, 2.0-2.5 mm long, fimbriate; tepals 4, opposite in two pairs, ovate, concave, ca $2.5 \times 1.0 \mathrm{~mm}$, fimbriate; stamens 4, 2-3 mm long; pistillode wider than high, ca $1.5 \times 1.0$ $\mathrm{mm}, 4$-angled. Female flowers pedicellate, ca $3 \mathrm{~mm}$ long, bicarpellate; tepals 4, ovate, ca $1.0-1.5 \mathrm{~mm}$ long, opposite in two pairs, fimbriate; ovary $1.5-2.0 \mathrm{~mm}$ long; interstylar nectaries present, bulged; styles 2, ca $1 \mathrm{~mm}$ long, recurved; stigma decurrent along ventral fold. Fruit a loculicidal capsule, dark green when young, dark purplish when ripe (fide Smitinand 4210), globose, ca $5 \mathrm{~mm}$ diameter, persistent 


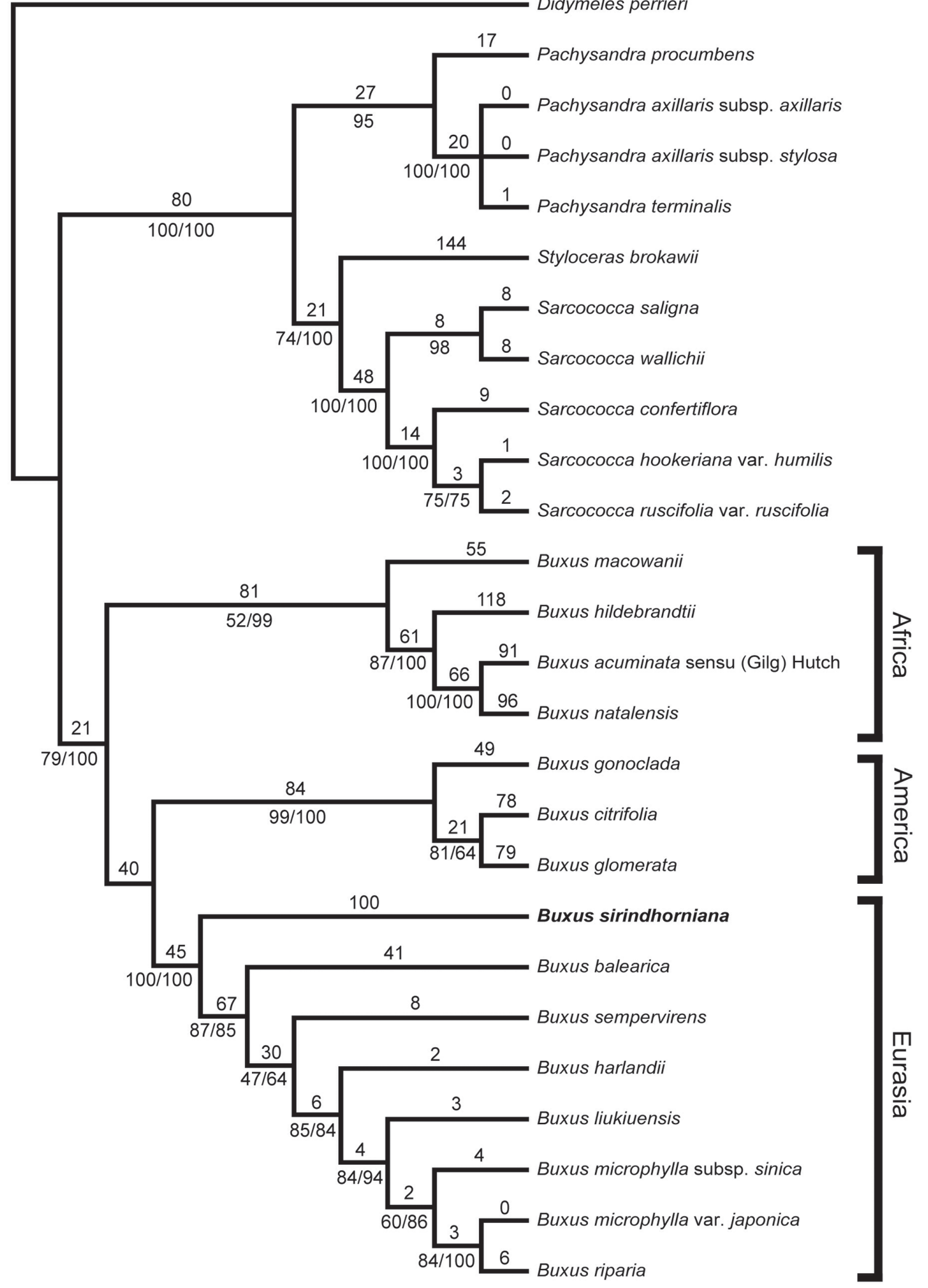

Figure 2. The single most parsimonious tree from the ITS data. Numbers above branches indicate branch lengths, numbers below branches are bootstrap values $>50 \%$ and numbers after slashes are posterior probability values $>50 \%$. 


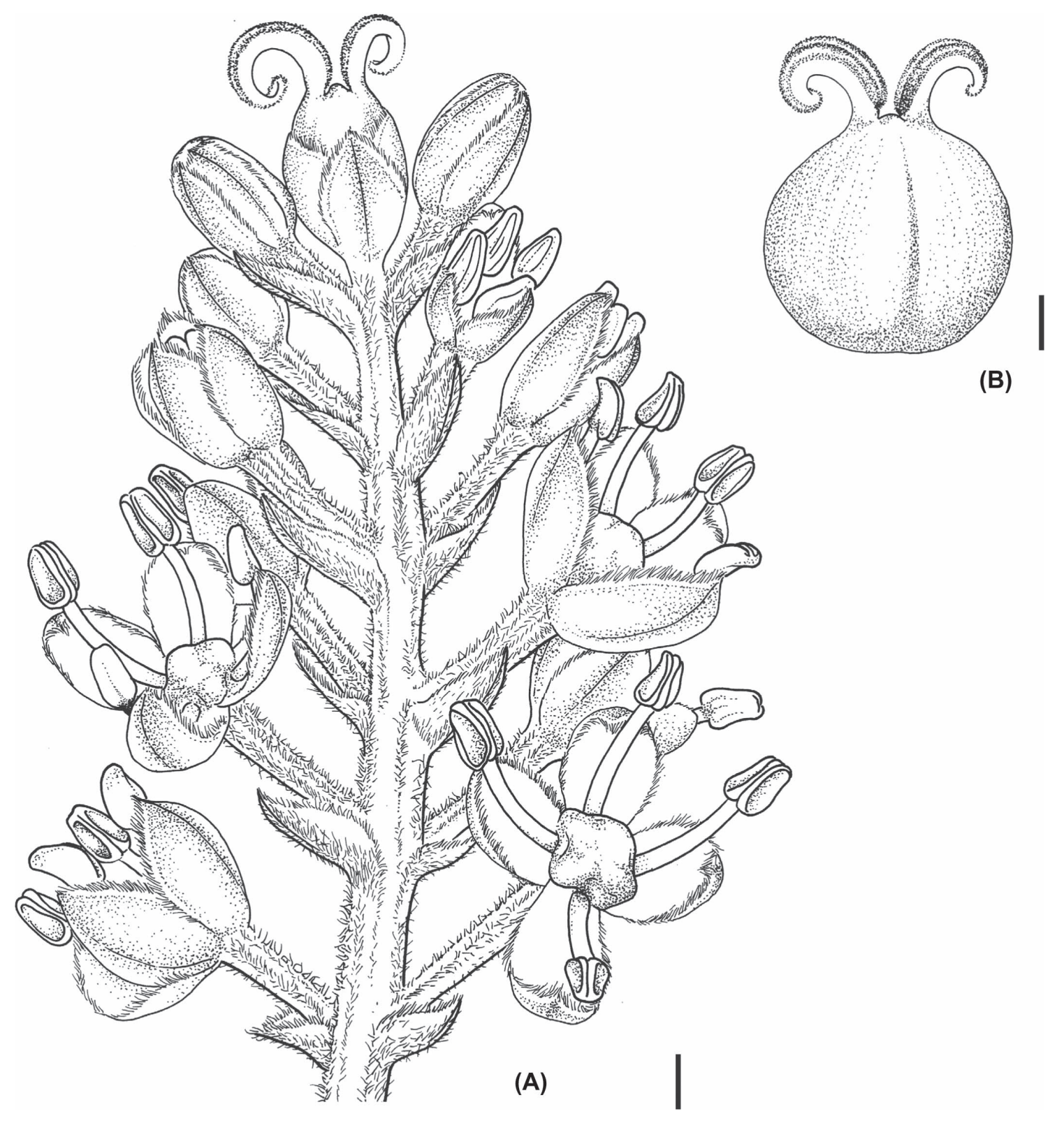

Figure 3. Buxus sirindihorniana sp. nov. (A) inflorescence, (B) fruit. Scale bar $=1 \mathrm{~mm}$. Drawn by Wuu Kuang Soh.

tepals appressed to base, orbicular, style persistent, recurved; pericarp thin, ca $0.2 \mathrm{~mm}$ thick; seeds 4 (2 per carpel), oblong, with testa black, shiny, and caruncle present.

\section{Phenology}

Flowering: July, November, December. Fruiting: January, February, June, July, November, December.

\section{Distribution, habitat and conservation status}

Buxus sirindhorniana is found in northeastern Thailand, Chiang Mai Province (Doi Chieng Dao National Park), Lumpang Province (Jae Sawn National Park) and Tak Province (Kao Hua Mot). It grows on exposed limestone ridges at $775-1525 \mathrm{~m}$ a.s.l. The species has been collected several times from Doi Chiang Dao, twice from Jae Sawn National Park and once from Kao Huat Mot. All these localities are protected areas and therefore the species does not strictly qualify for any of the IUCN threatened categories, and is thus provisionally assessed as 'Least Concern' (LC) under IUCN (2001).

\section{Notes}

A fruiting specimen, Kerr 6131, was identified by Sealy (1986) as $S$. coriacea based on the bicarpellate flower despite its decussate leaf arrangement which resembled Buxus. In Sarcococca, the inflorescence may be androgynous with the female flowers always at the distal part or wholly male or female. It is evident from the scars at the basal part of the inflorescence in Kerr 6131 that the male flowers may have fallen off, leaving behind the female flowers at the apex. This therefore gives a false impression that its inflorescence is wholly female. 
Additional specimens examined (paratypes)

Chiang Mai Province: Doi Chiang Dao, Chiang Dao Wildlife Sanctuary, 27 Jan 1996, Maxwell 96-113 (BKF); Doi Chiang Dao, Payap, 4 Dec 1965, Hennipman 3194 (holotype: BKF, isotype: K); Doi Chiang Dao, 1 Dec 1961, Smitinand and Anderson 7228 (K, BKF); Doi Chiang Dao, east slope, 16 Feb 1968, Smitinand 4210 (BKF); Doi Chiang Dao, 15 Jul 1958, Smitinand 4702 (BKF, K). Lampang Province: Jae Sawn National Park, northern part, 28 Jan 1996, Maxwell 96-1487 (BKF); Jae Sawn National Park, northern part, 19 Dec 1996, Maxwell 96-1672 (BKF). Tak Province: Kao Hua Mot, 13 Jun 1922, Kerr $6131(\mathrm{~K})$.

\section{Discussion}

In the ITS phylogeny, Buxus sirindhorniana was positioned at the base of the Eurasian Buxus clade within the larger Buxus clade (Fig. 2). A more extensive taxon sampling from an estimated total of 10 species in southeast Asia (Hatusima 1942) should further improve our understanding of the phylogenetic relationships and evolution of Eurasian Buxus.

Buxus sirindhorniana was considered allied to B. rupicola in having the same pollen type which is pantoporate and reticulate with smooth muri (Brückner 1993). In addition, Buxus rupicola is similar to $B$. sirindhorniana in having a hairy inflorescence and lacking intramarginal veins while differing in having an oblong-ovate leaves $(3-6 \times 1.2-$ $2.5 \mathrm{~cm}$ ) with rounded apecies (vs lanceolate with acute apex, $7.5-13 \times 1.5-2.8 \mathrm{~cm}$ ) and tricarpellate flowers (vs bicarpellate flowers). Buxus rupicola is a rare limestone species that is confined to the Langkawi Islands in northern Peninsular Malaysia bordering southern Thailand while $B$. sirindhorniana is confined to northern Thailand. The pollen type of $B$. rupicola and $B$. sirindhorniana is considered distinctive from other Eurasian Buxus (Brückner 1993) because of the smooth muri texture. The smooth and spatially branched muri on $B$. rupicola and $B$. sirindhorniana pollen resembled that of $B$. macrophylla from the neotropics (Köhler and Brückner 1989) while its eucamptodromous venation is similar to $B$. madagascarica from Madagascar and the Comoro Islands. In the revision of the Asiatic Buxus, Hatusima (1942) placed B. rupicola under the section Eubuxus in its own subgroup (Group 1).
The monoecious genera in the Buxaceae have a diverse inflorescence structure (von Balthazar and Endress 2000a, b). The Buxus clade (Fig. 2) consistently shares similar morphological characters including decussate leaves, inflorescence type, tricarpellate flowers, interstylodial nectaries and dehiscent 3-horned capsules (Köhler 2006). Buxus sirindhorniana is the first recorded solely bicarpellate Buxus species, though an anonymous referee has indicated that Madagascaran Buxus species are occasionally bicarpellate or 4-carpellate. Its fruit is interpreted as a dehiscent capsule, based on the putative dehiscing line on intact fruits in herbarium specimens. We have not, however, yet encountered specimens with mature dehiscent fruits. The pericarp is thin (ca $0.2 \mathrm{~mm}$ ) and unlike Buxus, the exocarp is not leathery. Based on herbarium labels, young fruits are dark green (Maxwell 96-113, Maxwell 96-1487, Maxwell 96-1672, Smitinand and Anderson 7228) maturing to dark purplish (Smitinand 4210). Though blackish fruits shaded red to purple occur in Buxus sect. Notobuxus, Pachysandra and Sarcococca, we are not aware of Eurasian Buxus species with dark purplish fruits. Other morphological characters in B. sirindhorniana, such as the leaf arrangement, inflorescence type and interstylodial nectaries, are the same as Buxus.

In the Pachysandra-Sarcococca-Styloceras clade, the reproductive characters are variable. In these three genera, the flowers can be bicarpellate and tricarpellate. Also, whilst the fruits of Sarcococca and Styloceras are drupaceous to subdrupaceous, those in Pachysandra can be either an indehiscent capsule or subdrupaceous (Köhler 2006) (Fig. 4). Our description of B. sirindhorniana means that the morphological diversity in the reproductive organs of the Pachysandra-Sarcococca-Styloceras clade is now paralleled in Buxus. Exceptionally, Buxus conzatii Standley and Styloceras laurifolium are similar to Sarcococca in having an alternate leaf arrangement, bicarpellate flowers and subdrupaceous to drupaceous fruits that lack interstylar nectaries but differ in having a terminal female flower (Fig. 4). The morphological diversity in the reproductive organs of the Pachysandra-Sarcococca-Styloceras clade can also be found in Buxus as demonstrated in B. sirindhorniana.

Interspecific hybrids among cultivars of Buxus are well known, for example between $B$. sempervirens and B. microphylla (Larson 1999) but natural hybrids among Buxaceae species including intergeneric hybrids have

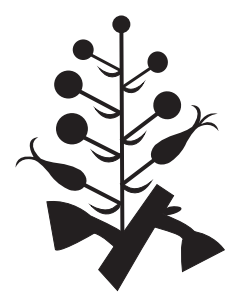

(A)

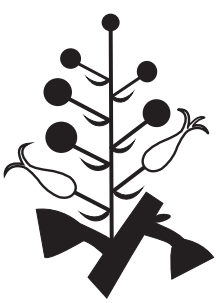

(B)

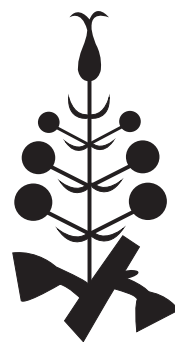

(C)

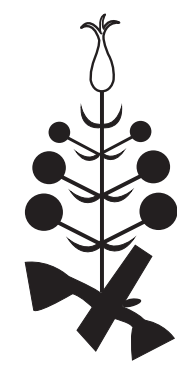

(D)

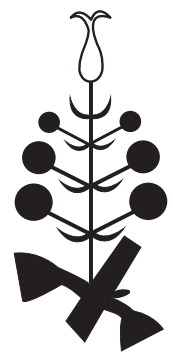

(E)

Figure 4. A schematic diagram of the monoecious inflorescence types in Buxaceae. The shaded female flower develops into a drupaceous or sub-drupaceous fruit. The hollow female flower develops into a capsule. (A) Pachysandra and Sarcococca, (B) Pachysandra, (C) Sarcococca conzattii and Styloceraslaurifolium, (D) Buxus, (E) Buxus sirindhorniana. 
not, to our knowledge, been documented. We are confident that $B$. sirindhorniana is not an intergeneric or interspecific hybrid because, firstly the pollen viability in $B$. sirindhorniana is high. Secondly, there are no polymorphic sites in the nucleotide sequences of the ITS ribosomal DNA which indicates that there are no different ITS tandem repeats present. An F1 hybrid or hybrid would inherit ITS types from each of the parental taxa (Hodkinson et al. 2002) and there is no evidence of this. Thirdly, the new species is morphologically distinct from other Asian Buxaceae species. Fourthly the species distribution only overlaps in one locality with Sarcococca species (S. balansae and $S$. coriaceae) in Doi Chieng Dao but not at all with Buxus. This implies that natural hybridisation from sympatric species of Buxus and Sarcococca is highly improbable. Finally, intergeneric hybridization is rare for distinct genera and is very unlikely for Buxus and Sarcococca since both genera are phylogenetically far apart.

Acknowledgements - We dedicate this paper to Maximilian von Sternburg our dear friend, co-author and colleague who unexpectedly died during the production of this paper. We are grateful to the curators of BKF, K, KEP, P, TCD and US for access to the specimens. We are thankful to Patricia Coughlan for the support she gave in the molecular work. Many thanks to Liam Furlong for the graphic, to Neal Leddy of the Trinity Centre for Microscopy and Analysis for help in the production of the SEM image and to Jan Frits Veldkamp for the Latin diagnosis.

\section{References}

Brückner, P. 1993. Pollen morphology and taxonomy of Eurasiatic species of the genus Buxus (Buxaceae). - Grana 32: 65-78.

Dafni, A. 1992. Pollination ecology: a practical approach. - Oxford Univ. Press.

Darriba, D. et al. 2012. jModelTest 2: more models, new heuristics and parallel computing. - Nature Methods 9: 772.

Erdtman, G. 1952. Pollen morphology and plant taxonomy 1 - angiosperms. - Almqvist and Wiksells, Stockholm.

Felsenstein, J. 1985. Confidence limits on phylogenies: an approach using the bootstrap. - Evolution 39: 783-791.

Hatusima, S. 1942. A revision of the Asiatic Buxus. - J. Dept Agricult. Kyushu Imp. Univ. 6: 261-342.

Hodkinson, T. R. et al. 2002. The use of DNA sequencing (ITS and trnL-F), AFLP and fluorescent in-situ hybridisation to study allopolyploid Miscanthus (Poaceae). - Am. J. Bot. 89: 279-286.

IUCN 2001. IUCN red list categories and criteria: ver. 3.1. - IUCN Species Survival Commission.

Supplementary material (Appendix NJB-00314 at <www. oikosoffice.lu.se/appendix $>$ ). Appendix A1.
Jiao, Z. and Li, J. 2009. Phylogenetics and biogeography of eastern Asian-North American disjunct genus Pachysandra (Buxaceae) inferred from nucleotide sequences. - Plant Syst. Evol. 47: 191-201.

Köhler, E. 2006. Buxaceae. - In: Kubitzki, K. (ed.), The families and genera of vascular plants. Vol. IX. Flowering plants. Springer, pp. $40-47$.

Köhler, E. and Brückner, P. 1989. The genus Buxus (Buxaceae): aspects of its differentiation in space and time. - Plant Syst. Evol. 162: 267-283.

Larson, P. D. 1999. Boxwood: its history, cultivation, propagation and descriptions. - Foliar Press, Virginia.

Liston, A. et al. 1996. Length variation in the nuclear ribosomal DNA internal transcribed spacer region of non-flowering seed plants. - Syst. Bot. 21: 109-120.

Nickrent, D. L. et al. 1994. A molecular phylogeny of Arceuthobium (Viscaceae) based on nuclear ribosomal DNA internal transcribed spacer sequences. - Am. J. Bot. 81: 1149-1160.

Parnell, J. A. N. et al. 2003. Plant collecting spread and densities; their potential impact on biogeographical studies in Thailand. - J. Biogeogr. 30: 1-18.

Rambaut, A. and Drummond, A. J. 2007. Tracer ver. 1.4 . - < http://beast.bio.ed.ac.uk/Tracer >, accessed 4 Apr 2013.

Ronquist, F. and Huelsenbeck, J. P. 2003. MRBAYES 3: Bayesian phylogenetic inference under mixed models. - Bioinformatics 19: $1572-1574$

Sealy, J. R. 1986. A revision of the genus Sarcococca (Buxaceae). - Bot. J. Linn. Soc. 92: 117-159.

Shipunov, A. and Shipunova, E. 2011. Haptanthus story: rediscovery of enigmatic flowering plant from Honduras. - Am. J. Bot. 98: 761-763.

Swofford, D. L. 2002. PAUP*. Phylogenetic analysis using parsimony (* and other methods), ver. 4.0b 10 (PPC). - Sinauer Associates.

Tropicos 2013. - < http://www.tropicos.org >, accessed 25 Jun 2013.

Vogel, E. F. de (ed.) 1987. Manual of herbarium taxonomy: theory and practice. - UNESCO Regional Office for Science and Technology for southeast Asia (Indonesia) ROSTSEA, Jakarta.

von Balthazar, M. et al. 2000. Phylogenetic relationships in Buxaceae based on nuclear internal transcribed spacers and plastid ndhF sequences. - Int. J. Plant Sci. 161: 785-792.

von Balthazar, M. and Endress, P. K. 2002a. Development of inflorescences and flowers in Buxaceae and the problem of perianth interpretation. - Int. J. Plant Sci. 163: 847-876.

von Balthazar, M. and Endress, P. K. 2002b. Reproductive structures and systematics of Buxaceae. - Bot. J. Linn. Soc. 140: 193-228.

White, T. J. et al. 1990. Amplification and direct sequencing of fungal ribosomal RNA genes for phylogenetics. - In: Innis, M. D. et al. (eds), PCR protocols: a guide to methods and application. Academic Press, pp. 315-322. 